\title{
Immunomodifiers in combination with conventional chemotherapy in small cell lung cancer: a Phase II, randomized study
}

This article was published in the following Dove Press journal:

Drug Design, Development and Therapy

22 July 2013

Number of times this article has been viewed

\author{
Konstantinos Zarogoulidis' \\ Eftimios Ziogas' \\ Efimia Boutsikou' \\ Paul Zarogoulidis ${ }^{1,2}$ \\ Kaid Darwiche ${ }^{2}$ \\ Theodoros Kontakiotis' \\ Kosmas Tsakiridis ${ }^{3}$ \\ Konstantinos Porpodis' \\ Dimitrios Latsios' \\ Olga Chatzizisi ${ }^{4}$ \\ Ilias Karapantzos ${ }^{5}$ \\ Qiang $\mathrm{Li}^{6}$ \\ Georgios Kyriazis ${ }^{2}$ \\ 'Pulmonary Department, \\ "G Papanikolaou" General Hospital, \\ Aristotle University of Thessaloniki, \\ Thessaloniki, Greece; ${ }^{2}$ Department \\ of Interventional Pneumology, \\ Ruhrlandklinik, West German Lung \\ Center, University Hospital, University \\ Duisburg-Essen, Essen, Germany; \\ ${ }^{3}$ Thoracic Surgery Department, "Saint \\ Luke" Private Hospital, Panorama, \\ Thessaloniki, Greece; " Immunology \\ Department, "G Papanikolaou" \\ General Hospital, Aristotle University \\ of Thessaloniki, Thessaloniki, Greece; \\ ${ }^{5}$ Ear, Nose and Throat Department, \\ "Saint Luke" Private Hospital, \\ Panorama, Thessaloniki, Greece; \\ ${ }^{6}$ Respiratory Diseases Department, \\ Shanghai hospital, Second Military \\ Medical University, Shanghai, People's \\ Republic of China
}

Correspondence: Paul Zarogoulidis

Pulmonary Department,

"G Papanikolaou" General Hospital,

Aristotle University of Thessaloniki,

Thessaloniki Exohi I I00, Greece 57010

Tel +3023 I 0992432

Fax +30 23I 0992433

Email pzarog@hotmail.com
Purpose: To evaluate the effect of immunotherapy on response, survival, and certain immune markers in patients with small cell lung cancer (SCLC) who are receiving chemotherapy.

Patients and methods: Patients with SCLC $(\mathrm{n}=164)$ were assigned to receive either chemotherapy alone (group A) or a combination of chemotherapy and immunotherapy as follows: interferon $\alpha$ (IFN- $\alpha$; 3 million IU) 3 times per week (group B); IFN- $\gamma$ ( 3 million IU) 3 times per week (group C); and IFN- $\alpha$ and IFN- $\gamma$ (1.5 million IU of each) 3 times per week (group D). Chemotherapy was the same for all groups and consisted of eight cycles with carboplatin $5.5 \mathrm{mg} / \mathrm{m}^{2}$ intravenously on day 1 , ifosfamide $3.5 \mathrm{mg} / \mathrm{m}^{2}$ intravenously on day 1 , and etoposide $200 \mathrm{mg} / \mathrm{m}^{2}$ total dose taken orally on days 1 through 3, every 28 days. Patients completing chemotherapy were restaged, and those who were found to have limited disease received primary site and prophylactic cranial irradiation. Immunotherapy was continued throughout these treatments and during the follow-up period. Blood was taken before each course of chemotherapy and during follow-up to measure CD3+ lymphocytes, CD3+CD4+ lymphocytes, CD3+CD8+ lymphocytes, natural killer cells, and natural killer T cells.

Results: Differences in response and survival were not significantly different when all patients were considered. However, among patients with limited disease, Kaplan-Meier analysis disclosed a survival benefit for group $\mathrm{B}(P<0.05)$. The analysis of immunologic measurements revealed that the improvement of immune markers was always accompanied by clinical improvement, whereas deterioration of all markers was accompanied by disease progression (result not statistically significant except for group $\mathrm{C} ; P<0.05$ ).

Conclusion: Among cytokines used in the study, only IFN- $\alpha$ seems to confer a survival benefit to patients with SCLC with limited disease. However, immunotherapy remains a challenge in the treatment of lung neoplasms and should be further explored.

Keywords: interferon, SCLC, lung cancer, immunomodifiers

\section{Introduction}

Cancer immunotherapy attempts to stimulate the immune system to reject and destroy tumors. The concept of this treatment started in the United States in the 1980s in randomized controlled studies in different cancers, resulting in reported significant increases in survival and disease-free period. ${ }^{1-3}$ Its efficacy is enhanced by $20 \%-30 \%$ when cell-based immunotherapy is combined with other conventional treatment methods.

Interferon (IFN) was one of the first cytokines found to have anticancer effects, and it was introduced into the combined modality regimens used to treat small cell lung cancer (SCLC) in the early 1980s in an attempt to overcome the problem of early relapse. IFNs are a group of proteins and glycoproteins produced by cells in response 
to viral stimulation. ${ }^{4}$ IFNs have immunoregulatory effects on antibody production, natural killer (NK) and T cell activation, macrophage function, delayed-type hypersensitivity, and major histocompatibility complex molecule expression. ${ }^{5-7}$ They have also been shown to have antiproliferative effects and antiangiogenic properties. ${ }^{8}$ Type 1 IFNs (the IFN- $\alpha$ family and IFN- $\beta$ ) are known to inhibit tumor cell growth and stimulate the immune system. ${ }^{9}$ It has also been demonstrated that recombinant IFN- $\gamma$ induces immunomodulation and has antiproliferative activity. Combinations of IFN- $\alpha$ and IFN- $\gamma$ demonstrate synergistic antiviral and antiproliferative activity. ${ }^{10-12}$ In addition, synergistic or additive interactions between IFN- $\alpha$ and cytotoxic drugs, particularly cisplatin, have been demonstrated in the experimental setting ${ }^{13-15}$ and in clinical Phase II studies. ${ }^{16}$

However, only a few randomized clinical trials have been conducted to evaluate the possible advantage of adding immunomodifiers to conventional induction therapy. ${ }^{17}$ In the past, our group has reported significant antitumor activity of IFN- $\alpha$ and improved survival in patients with SCLC. ${ }^{18}$ The aim of this study was to determine whether in patients with SCLC the addition of either IFN- $\alpha$ or IFN- $\gamma$ or their combination with standard induction chemotherapy would improve response rates and survival at acceptable toxicity. Furthermore, we evaluated the immunological responses in the peripheral blood by measuring the levels of NKs and some subsets of $\mathrm{T}$ lymphocytes (CD4+ T cells, CD8+ T cells, and NK T cells [CTLs]) and determining whether these immunoregulatory observations correlated with the progress of the disease.

\section{Patients and methods}

\section{Study subjects}

Chemo-naïve patients with histology-confirmed SCLC (limited or extensive disease), according to the Veterans
Administration Lung Study Group definition modified by the International Association for the Study of Lung Cancer, were eligible. Exclusion criteria included age $>72$ years, Karnofsky index $<70$, central nervous system metastasis at the time of diagnosis, creatinine clearance lower than $60 \mathrm{~mL} /$ min, and serious concomitant disease. From our department, 170 patients were initially recruited, from whom 164 patients were finally evaluable for assessment of response and toxicity. Patients' characteristics are summarized in Table 1. Pretreatment investigations included: general medical examination; chest radiography and computed tomography of the chest, upper abdomen, and brain; tissue sampling by bronchoscopy or mediastinoscopy; and a bone scan. The study was approved by the institutional review board of "G Papanikolaou" General Hospital and the Aristotle University of Thessaloniki. All patients signed an informed consent form.

\section{Study design}

A randomized, nonblinded trial was conducted. Randomization was stratified for stage, and patients were divided into four groups as follows: group A, the control group, received conventional chemotherapy; group B received chemotherapy and IFN- $\alpha$ (3 million IU) subcutaneously three times a week; group $\mathrm{C}$ received IFN- $\gamma$ (3 million IU) subcutaneously three times a week; and group D received IFN- $\alpha$ and IFN- $\gamma$ (1.5 million IU of each) 3 times a week subcutaneously.

Chemotherapy was the same for all groups and consisted of eight cycles with carboplatin $5.5 \mathrm{mg} / \mathrm{m}^{2}$ intravenously on day 1 , ifosfamide $3.5 \mathrm{~g} / \mathrm{m}^{2}$ intravenously (with mesna) on day 1 , and etoposide $200 \mathrm{mg} / \mathrm{m}^{2}$ total dose taken orally on days 1 through 3 , every 28 days, which has been shown to improve overall survival compared with standard chemotherapy in the LU21 trial. ${ }^{19-21}$ After the completion of eight cycles of chemotherapy, patients were restaged by computed tomography scans of the brain, thorax, and upper abdomen. Those

Table I Patients' characteristics

\begin{tabular}{|c|c|c|c|c|}
\hline & $\begin{array}{l}\text { Group A } \\
\text { (control group) }\end{array}$ & $\begin{array}{l}\text { Group B } \\
(\text { IFN- } \alpha)\end{array}$ & $\begin{array}{l}\text { Group C } \\
(\text { IFN- } \gamma)\end{array}$ & $\begin{array}{l}\text { Group D } \\
\text { (IFN- } \alpha \text { and IFN- } \gamma \text { ) }\end{array}$ \\
\hline Patients, $\mathrm{n}$ & 48 & 39 & 35 & 42 \\
\hline Median age, years & 60 & 62 & 58 & 56 \\
\hline Male/Female & $47 / 1$ & $37 / 2$ & $35 / 0$ & $40 / 2$ \\
\hline \multicolumn{5}{|l|}{ Clinical stage } \\
\hline Limited, n (\%) & $17(35)$ & $16(4 I)$ & $13(37)$ & $16(38)$ \\
\hline Extensive, n (\%) & $31(65)$ & $23(59)$ & $22(63)$ & $26(62)$ \\
\hline \multicolumn{5}{|l|}{ Karnofsky index } \\
\hline $100 \%-90 \%$, n (\%) & $20(42)$ & $18(46)$ & $15(43)$ & $17(4 I)$ \\
\hline 80\%-70\%, n (\%) & $28(58)$ & $21(54)$ & $20(57)$ & $25(60)$ \\
\hline
\end{tabular}

Abbreviations: IFN- $\alpha$, interferon alpha; IFN- $\gamma$, interferon gamma; $n$, number. 
found to have limited disease received primary site irradiation (45-50 Gy in 25 fractions) and prophylactic cranial irradiation (25 Gy in 12 fractions). ${ }^{22}$ Immunotherapy was continued throughout these treatments and during the follow-up period as maintenance therapy. Antiemetic treatment consisted of 5-hydroxytryptamine receptor antagonists, and acetaminophen $500 \mathrm{mg}$ was given to treat IFN-related influenza-like symptoms. Patients in the chemotherapy group were followed up without maintenance therapy. Blood was taken before each course of chemotherapy and during follow-up to measure the total amount of $\mathrm{T}$ lymphocytes and their subgroups CD4+ T cells, CD8+ T cells, NKT (natural killer T) cells, and NK cells. Response and toxicity were evaluated according to World Health Organization criteria. Patients who showed disease progression at any time were taken off study medication but were followed up for survival analysis.

The study was initiated in May 2004, and patient enrollment ended on February 2007. Follow-up data were collected up to May 2010.

The primary end-point of the study was survival; the secondary end points were response after induction therapy and the fluctuation of the immunologic indices during the course of the disease (Figure 1).

\section{Analysis}

Statistical analysis was performed using the Statistical Package for the Social Sciences (SPSS; IBM Corporation, Armonk, NY, USA). Differences in the four groups for clinical characteristics, response, and toxicity were assessed by chi-square statistics. Survival was compared using KaplanMeier statistics and log-rank test. A $P$-value of $<0.05$ was considered significant.

\section{Results}

From 170 patients initially recruited, 164 were finally eligible for assessment. From six patients who were not evaluated, four were excluded because of violation of protocol, and two patients in group $\mathrm{C}$ were lost because they did not attend. Response rates for all evaluable patients are summarized in Table 2. Median survival was 10 months for group A (95\% confidence interval [CI], 9.3-10.6 months), 10.3 months for group B (95\% CI, 7.13-13.5 months), 8.3 months for group C (95\% CI, 6.8-9.8 months), and 11 months (95\% CI, 9.2-12.8 months) for group D. If we compare all groups together, there is no significant difference in survival, even with pairwise comparison among four groups $(P>0.05)$. Interestingly, when patients with

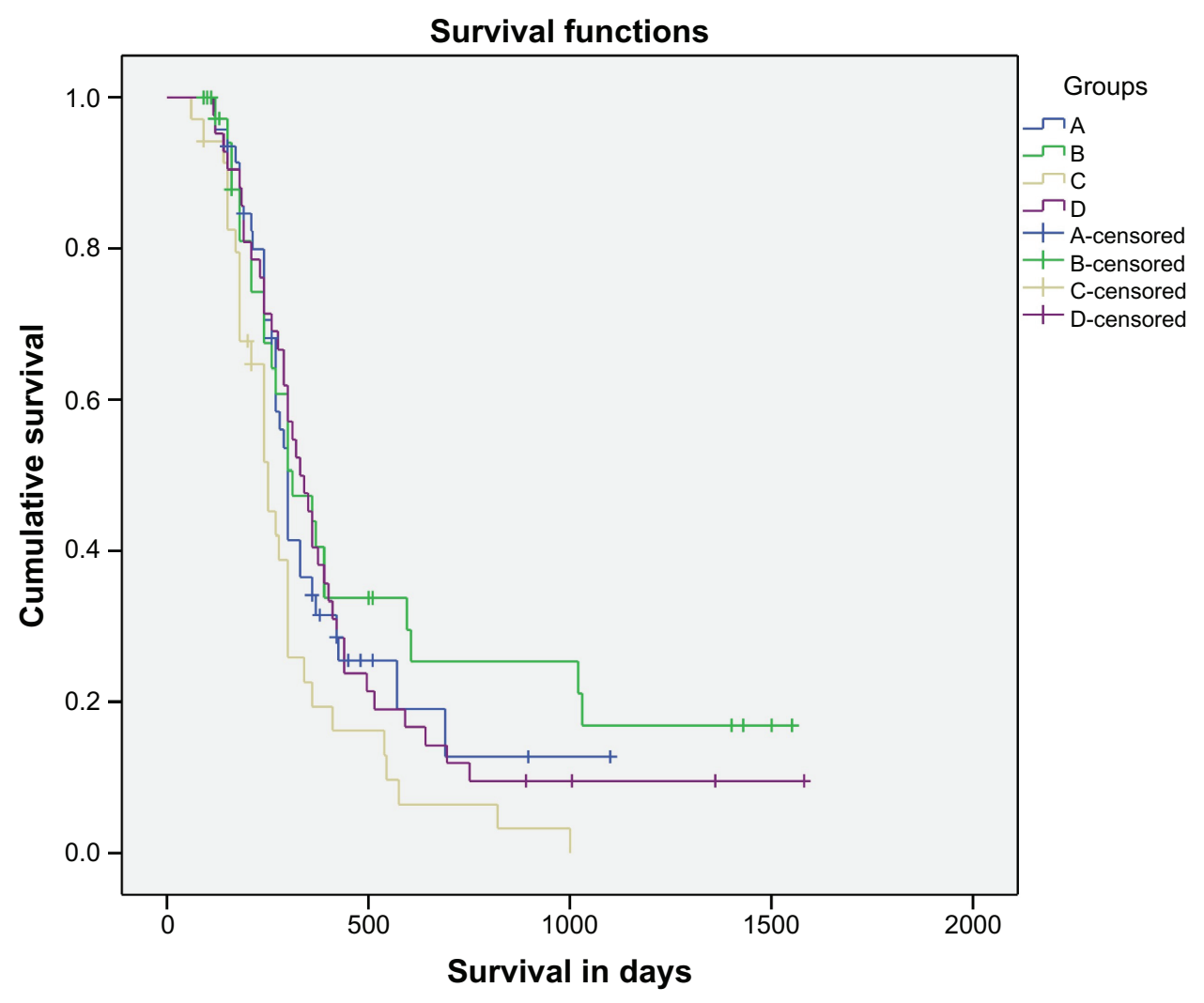

Figure I Survival in days for all stages.

Notes: group A, chemotherapy alone; group B, chemotherapy and IFN- $\alpha$; group C, chemotherapy and IFN- $\gamma$; group D, chemotherapy and both IFN- $\alpha$ and IFN- $\gamma$. Abbreviations: IFN- $\alpha$, interferon alpha; IFN- $\gamma$, interferon gamma. 
Table 2 Response rates

\begin{tabular}{lllll}
\hline & $\begin{array}{l}\text { Group A } \\
\text { (control group) }\end{array}$ & $\begin{array}{l}\text { Group B } \\
\text { (IFN- } \boldsymbol{\alpha})\end{array}$ & $\begin{array}{l}\text { Group C } \\
\text { (IFN- } \boldsymbol{\gamma})\end{array}$ & $\begin{array}{l}\text { Group D } \\
\text { (IFN- } \boldsymbol{\alpha} \text { and IFN- } \boldsymbol{\gamma})\end{array}$ \\
\hline Patients & 48 & 39 & 35 & 42 \\
Complete response & $10(21)$ & $8(20.5)$ & $3(9)$ & $12(29)$ \\
Partial response & $19(40)$ & $18(46)$ & $13(37)$ & $19(45)$ \\
Stable disease & $11(30)$ & $5(13)$ & $7(20)$ & $7(17)$ \\
Progressive disease & $8(17)$ & $8(20.5)$ & $12(34)$ & $4(10)$ \\
\hline
\end{tabular}

Note: Values are presented as absolute numbers, and percentages in parentheses.

Abbreviations: IFN- $\alpha$, interferon alpha; IFN- $\gamma$, interferon gamma.

only limited disease were considered, a significant survival benefit in group B was revealed compared with control group A $(P=0.039)$, group $\mathrm{C}(P<0.005)$, and group D $(P=0.038)$. Median survival for each group in all stages and for limited disease separately is shown in Table 3. Ten patients in the IFN- $\alpha$ group (25\%) and two in group D (IFN- $\alpha$ and IFN- $\gamma$ ), but none in the other groups, survived for 3 years or longer.

\section{Immune markers analysis}

Fluctuations in lymphocyte levels for each patient group are shown in Table 4. Assessment of fluctuations was based on three different time measurements: before treatment initiation; before the fourth cycle of treatment; and at the time of disease progression. The analysis of immunological measurements revealed improvement of immune markers accompanied by clinical improvement, whereas deterioration of all markers was accompanied, although not significantly, by disease progression (time series analysis $P<0.05$; Figures 2 and 3).

\section{Toxicity}

Toxicity data are summarized in Table 5. Immunotherapy was well tolerated. Significantly more patients in the immunotherapy groups than in the chemotherapy group experienced

Table 3 Median survival in months

\begin{tabular}{lll}
\hline & $\begin{array}{l}\text { Median survival } \\
\text { in months (limited } \\
\text { disease + ED) }\end{array}$ & $\begin{array}{l}\text { Median survival in } \\
\text { months (limited } \\
\text { disease only) }\end{array}$ \\
\hline $\begin{array}{l}\text { Group A } \\
\text { control group) }\end{array}$ & $10(95 \% \mathrm{Cl}, 9.3-10.6)$ & $19(95 \% \mathrm{Cl}, 7.8-30)$ \\
$\begin{array}{l}\text { Group B } \\
\text { (IFN- } \alpha)\end{array}$ & $10.3(95 \% \mathrm{Cl}, 7.13-13.5)$ & $34(95 \% \mathrm{Cl}, 30-48)$ \\
$\begin{array}{l}\text { Group C } \\
\text { IFN- } \alpha+\text { IFN- } \gamma)\end{array}$ & $8.3(95 \% \mathrm{Cl}, 6.8-9.8)$ & $13.6(95 \% \mathrm{Cl}, 3.8-23)$ \\
$\begin{array}{l}\text { Group D } \\
\text { (IFN- } \gamma)\end{array}$ & $1 \mathrm{I}(95 \% \mathrm{Cl}, 9.2-12.8)$ & $17(95 \% \mathrm{Cl}, \mathrm{II}-23)$ \\
\hline
\end{tabular}

Abbreviations: $\mathrm{Cl}$, confidence interval; $\mathrm{ED}$, extensive disease; IFN- $\alpha$, interferon alpha; IFN- $\gamma$, interferon gamma. toxicity, but in groups B, C, and D, symptoms were mild and well manageable. Neutropenia was higher $(P<0.0001)$ in the IFN- $\gamma$ group.

\section{Discussion}

The aim of this study was to investigate, in a randomized trial, the efficacy of adjunctive immunotherapy in SCLC therapy. Our previous pilot study ${ }^{17}$ has shown that combination therapy with IFN- $\alpha$ is effective for SCLC, particularly in those patients with limited disease. The present trial has confirmed that the addition of IFN- $\alpha$ provides a good survival benefit in limited SCLC, whereas administration of IFN- $\gamma$ has no place as monotherapy in SCLC treatment. ${ }^{23,24}$

Immunomodulatory activity of IFN- $\alpha$ and IFN- $\gamma$ concerned in intensification of major histocompatibility complex I and II molecule expression in cancer cells surface, thereby increasing the recognition and killing of these cells. IFNs also directly activate other immune cells, such as macrophages

Table 4 Mean values of fluctuation of immune markers

\begin{tabular}{lllll}
\hline & Group A & Group B & Group C & Group D \\
\hline CD3+ I & 1600 & 1620 & 1880 & 1280 \\
CD3+2 & 1850 & 1750 & 1700 & 1570 \\
CD3+3 & 1400 & 1480 & 1350 & 900 \\
CD3+CD4+ I & 900 & 1060 & 1200 & 800 \\
CD3+CD4+2 & 1050 & 1200 & 1100 & 900 \\
CD3+CD4+3 & 700 & 880 & 1200 & 450 \\
CD3+CD8+ I & 600 & 550 & 880 & 500 \\
CD3+CD8+2 & 780 & 580 & 1100 & 650 \\
CD3+CD8+3 & 650 & 600 & 620 & 450 \\
NK-1 & 300 & 210 & 350 & 200 \\
NK-2 & 350 & 280 & 300 & 200 \\
NK-3 & 200 & 250 & 200 & 150 \\
NKT-I & 150 & 200 & 190 & 100 \\
NKT-2 & 180 & 180 & 250 & 120 \\
NKT-3 & 150 & 185 & 160 & 100 \\
\hline Notes: & & &
\end{tabular}

Notes: group A, chemotherapy alone; group B, chemotherapy and IFN- $\alpha$; group $C$, chemotherapy and IFN- $\gamma$; group $D$, chemotherapy and both IFN- $\alpha$ and IFN- $\gamma$.

Abbreviations: NK, natural killer; NKT, natural killer T cell; IFN- $\alpha$, interferon alpha; IFN- $\gamma$, interferon gamma. 


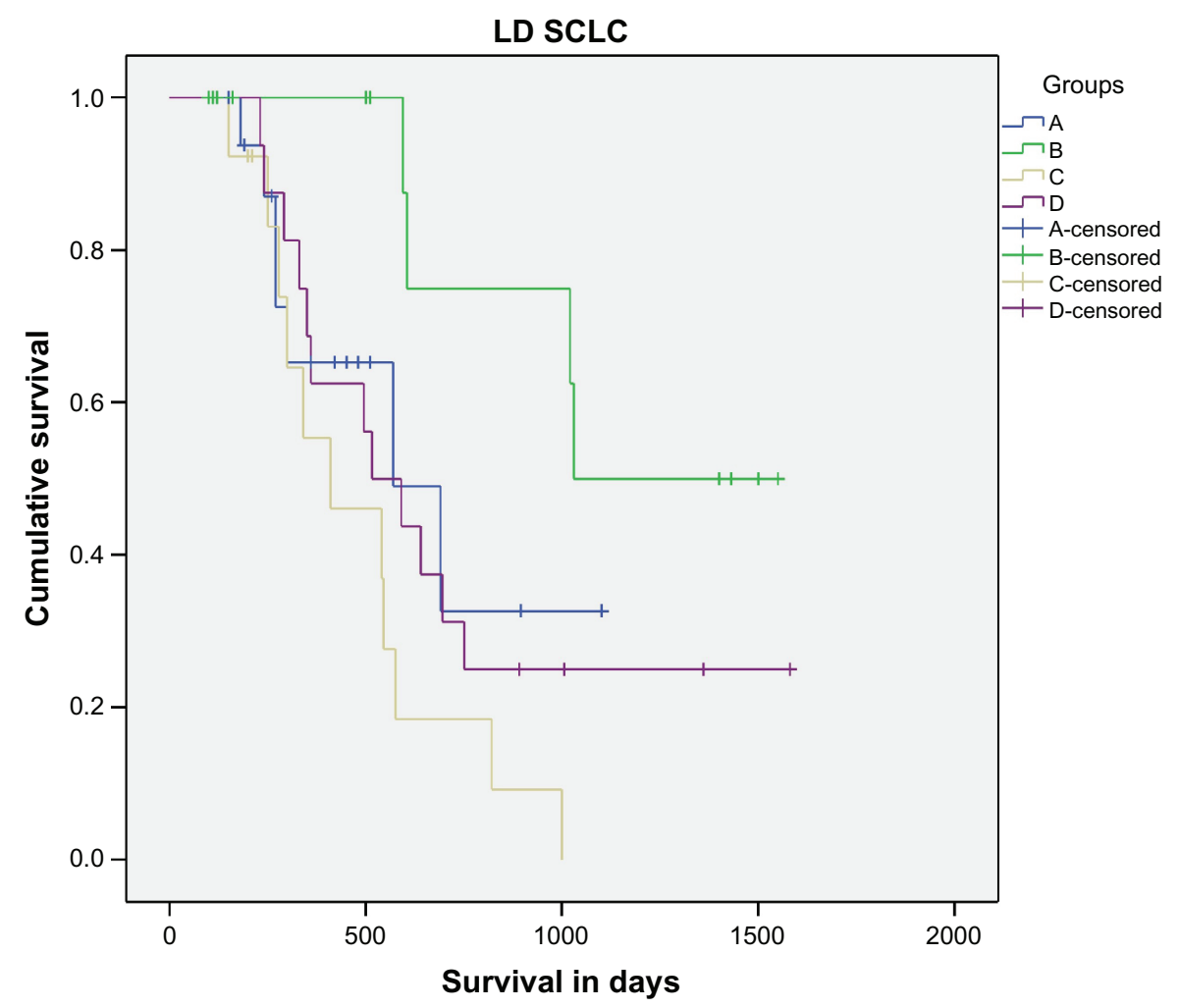

Figure 2 Survival in days for limited disease.

Notes: group A, chemotherapy alone; group B, chemotherapy and IFN- $\alpha$; group C, chemotherapy and IFN- $\gamma$; group D, chemotherapy and both IFN- $\alpha$ and IFN- $\gamma$. Abbreviations: LD SCLC, limited disease small cell lung cancer; IFN- $\alpha$, interferon alpha; IFN- $\gamma$, interferon gamma.

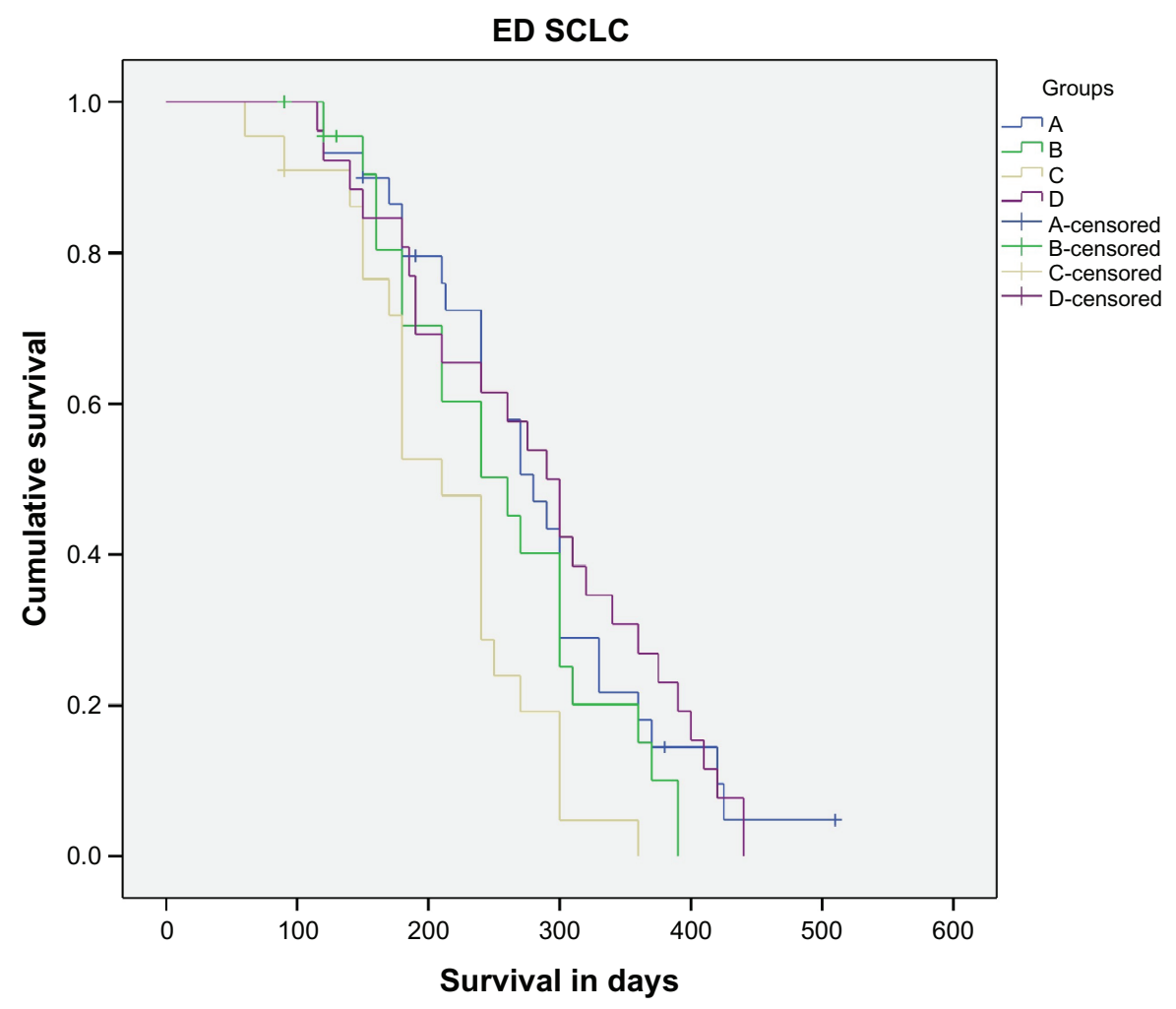

Figure 3 Survival in days for extensive disease.

Notes: group A, chemotherapy alone; group B, chemotherapy and IFN- $\alpha$; group C, chemotherapy and IFN- $\gamma$; group D, chemotherapy and both IFN- $\alpha$ and IFN- $\gamma$. Abbreviations: ED SCLC, extensive disease small cell lung cancer; IFN- $\alpha$, interferon alpha; IFN- $\gamma$, interferon gamma. 
Table 5 Toxicity: patients who suffered at least one single event

\begin{tabular}{|c|c|c|c|c|}
\hline & $\begin{array}{l}\text { Group A } \\
\text { (control group) }\end{array}$ & $\begin{array}{l}\text { Group B } \\
\text { (IFN- } \alpha)\end{array}$ & $\begin{array}{l}\text { Group C } \\
(\text { IFN- } \gamma)\end{array}$ & $\begin{array}{l}\text { Group D } \\
\text { (IFN- } \alpha \text { and IFN- } \gamma \text { ) }\end{array}$ \\
\hline Patients & 48 & 39 & 35 & 42 \\
\hline Fever & $7(15)$ & $14(35)$ & $12(34)$ & $17(40)$ \\
\hline Anorexia & $19(40)$ & $21(60)$ & $20(56)$ & $27(65)$ \\
\hline Fatigue & II (22) & $16(40)$ & $13(38)$ & $21(50)$ \\
\hline \multicolumn{5}{|l|}{ Anemia } \\
\hline Grade I/2 & 19 & 11 & 12 & 10 \\
\hline Grade 3 & 3 & 2 & 4 & 5 \\
\hline \multicolumn{5}{|l|}{ Neutropenia } \\
\hline Grade I/2 & 19 & 10 & 19 & $34(P<0.00 I)$ \\
\hline Grade 3/4 & 4 & 3 & 5 & 7 \\
\hline \multicolumn{5}{|c|}{ Thrombocytopenia } \\
\hline Grade I/2 & 6 & 2 & 2 & 4 \\
\hline Grade 3/4 & 5 & 6 & 4 & 3 \\
\hline
\end{tabular}

Note: Values are presented as absolute numbers, and percentage in parentheses.

Abbreviations: IFN- $\alpha$, interferon alpha; IFN- $\gamma$, interferon gamma.

and NK cells, with the difference being that IFN- $\gamma$ protects cancer cells from the lytic activity of NK cells, ${ }^{25}$ which partly explains the absence of therapeutic effect in patients in group $\mathrm{C}$, who received IFN- $\gamma$ only. IFN- $\gamma$ seems to have lower direct antitumor activity compared with either IFN- $\alpha$ alone or IFN- $\alpha$ and IFN- $\gamma$ in combination, as shown in cancer cell lines. ${ }^{26}$

Clinically, IFN- $\alpha$ proved to be effective in the treatment of hairy cell leukemia and chronic myelogenous leukemia. ${ }^{27}$ In contrast, many other tumors, among them SCLC, seem to resist cytokines, but they respond to IFNs in their early stage. ${ }^{28}$ One hypothesis is that the reset of the immune system in limited disease is faster than in extensive disease; this is also an explanation for the better response of limited disease in general. Another possible explanation could be that despite chemotherapy affecting the immune system of the host negatively, IFNs exert a positive influence on the immune system, and patients with limited disease have more reserve to respond to IFN stimuli.

Immunological studies have shown that SCLC suppresses cytokine secretion by lymphocytes. Fischer et $\mathrm{al}^{29}$ found significant reduction of interleukin 2 , IFN- $\alpha$, IFN- $\gamma$, and tumor necrosis factor in patients with SCLC, which improved after tumor control with chemotherapy. This immunomodulatory activity of chemotherapy seems to partly explain both the improvement of immune marker levels in patients who responded in chemotherapy and also the deterioration of them when patients experienced progressive disease in the control group. However, the lack of clinical effect is an indication of insufficient activation of cells produced or weakness of migration at the tumor site, evidenced by their appearance in large numbers in the peripheral blood.

The results of this study must be interpreted with caution. First, the total number of patients investigated was small; this is the main limitation of the study. Second, relatively low doses of cytotoxic agents were chosen to avoid a potentiation of the myelosuppressive effect by IFNs. ${ }^{14}$

Toxicity was characterized by fever and a higher grade of myelosuppression in the IFN groups, as could have been expected. Increased neutropenia in group D shows increased toxicity when IFNs are combined rather than received alone, even if their total dose remains the same. However, no major delays in treatment were observed in the IFN groups.

Smoking habits in females begin later compared with European and North American females. That is why SCLC is uncommon in women and why the vast majority of patients enrolled in the study are men. ${ }^{30}$

\section{Conclusion}

In summary, among the cytokines used in this study, only IFN- $\alpha$ appears to confer a survival benefit to patients with SCLC who have limited disease. Because of the low number of randomized patients, the clinical relevance of these findings remains to be defined. Further clinical studies on the efficacy of IFN- $\alpha$ as an adjunctive and/or maintenance treatment are warranted, as immunotherapy remains a challenge for the treatment of lung neoplasms.

\section{Disclosure}

The authors report no conflicts of interest in this work. 


\section{References}

1. Kimura H, Yamaguchi Y. A phase III randomized study of interleukin-2 lymphokine-activated killer cell immunotherapy combined with chemotherapy or radiotherapy after curative or noncurative resection of primary lung carcinoma. Cancer. 1997;80(1):42-49.

2. Takayama T, Sekine T, Makuuchi M, et al. Adoptive immunotherapy to lower postsurgical recurrence rates of hepatocellular carcinoma: a randomised trial. Lancet. 2000;356(9232):802-807.

3. Kono K, Takahashi A, Ichihara F, et al. Prognostic significance of adoptive immunotherapy with tumor-associated lymphocytes in patients with advanced gastric cancer: a randomized trial. Clin Cancer Res. 2002;8(6):1767-1771.

4. Folkman J, Klagsbrun M. Angiogenic factors. Science. 1987;235(4787): 442-447.

5. Biron CA. Role of early cytokines, including alpha and beta interferons (IFN-alpha/beta), in innate and adaptive immune responses to viral infections. Semin Immunol. 1998;10(5):383-390.

6. Pfeffer LM, Dinarello CA, Herberman RB, et al. Biological properties of recombinant alpha-interferons: 40th anniversary of the discovery of interferons. Cancer Res. 15 1998;58(12):2489-2499.

7. Sen GC, Lengyel P. The interferon system. A bird's eye view of its biochemistry. J Biol Chem. 1992;267(8):5017-5020.

8. Brem H, Gresser I, Grosfeld J, Folkman J. The combination of antiangiogenic agents to inhibit primary tumor growth and metastasis. $J$ Pediatr Surg. 1993;28(10):1253-1257.

9. Lengyel P. Biochemistry of interferons and their actions. Annu Rev Biochem. 19851:251-282.

10. Kurzrock R, Rosenblum MG, Quesada JR, Sherwin SA, Itri LM, Gutterman JU. Phase I study of a combination of recombinant interferon-alpha and recombinant interferon-gamma in cancer patients. J Clin Oncol. 1986;4(11):1677-1683.

11. Hand A, Pelin K, Halme M, et al. Interferon-alpha and interferon-gamma combined with chemotherapy: in vitro sensitivity studies in non-small cell lung cancer cell lines. Anticancer Drugs. 1993;4(3):365-368.

12. Zarogoulidis P, Kioumis I, Papanas N, et al. The effect of combination IFN-alpha-2a with usual antituberculosis chemotherapy in nonresponding tuberculosis and diabetes mellitus: a case report and review of the literature. J Chemother. 2012;24(3):173-177.

13. Wadler S, Schwartz EL. Antineoplastic activity of the combination of interferon and cytotoxic agents against experimental and human malignancies: a review. Cancer Res. 1990;50(12):3473-3486.

14. Aapro MS, Alberts DS, Salmon SE. Interactions of human leukocyte interferon with vinca alkaloids and other chemotherapeutic agents against human tumors in clonogenic assay. Cancer Chemother Pharmacol. 1983;10(3):161-166.

15. Carmichael J, Fergusson RJ, Wolf CR, Balkwill FR, Smyth JF. Augmentation of cytotoxicity of chemotherapy by human alphainterferons in human non-small cell lung cancer xenografts. Cancer Res. 1986;46(10):4916-4920.
16. Bonnem EM. Alfa interferon: combinations with other antineoplastic modalities. Semin Oncol. 1987;14(2 Suppl 2):48-60.

17. Mattson K, Nea A. Concomitant chemotherapy (CT) and interferonalpha (IFN alpha) for SCLC. Proc Am Soc Clin Oncol. 1995;14:370.

18. Zarogoulidis K, Ziogas E, Papagiannis A, et al. Interferon alpha-2a and combined chemotherapy as first line treatment in SCLC patients: a randomized trial. Lung Cancer. 1996;15(2):197-205.

19. Thatcher N, Cerny T, Stout R, et al. Ifosfamide, etoposide, and thoracic irradiation therapy in 163 patients with unresectable small cell lung cancer. Cancer. 1987;60(10):2382-2387.

20. Thatcher N, Qian W, Clark PI, et al. Ifosfamide, carboplatin, and etoposide with midcycle vincristine versus standard chemotherapy in patients with small-cell lung cancer and good performance status: clinical and quality-of-life results of the British Medical Research Council multicenter randomized LU21 trial. J Clin Oncol. 2005;23(33): 8371-8379.

21. Rossi A, Di Maio M, Chiodini P, et al. Carboplatin- or cisplatinbased chemotherapy in first-line treatment of small-cell lung cancer: the COCIS meta-analysis of individual patient data. J Clin Oncol. 2012;30(14):1692-1698.

22. McCracken JD, Janaki LM, Crowley JJ, et al. Concurrent chemotherapy/ radiotherapy for limited small-cell lung carcinoma: a Southwest Oncology Group Study. J Clin Oncol. 1990;8(5):892-898.

23. Jett JR, Maksymiuk AW, Su JQ, et al. Phase III trial of recombinant interferon gamma in complete responders with small-cell lung cancer. J Clin Oncol. 1994;12(11):2321-2326.

24. Pohl WR. Interferon therapy of the lung and locoregional therapy in pulmology. Wien Med Wochenschr. 1993;143(16-17):450-454.

25. Malmberg KJ, Levitsky V, Norell H, et al. IFN-gamma protects shortterm ovarian carcinoma cell lines from CTL lysis via a CD94/NKG2Adependent mechanism. J Clin Invest. 2002;110(10):1515-1523.

26. Tanio Y, Watanabe M, Osaki T, et al. High sensitivity to peripheral blood lymphocytes and low HLA-class I antigen expression of small cell lung cancer cell lines with diverse chemo-radiosensitivity. Jpn J Cancer Res. 1992;83(7):736-745.

27. Gutterman JU. Cytokine therapeutics: lessons from interferon alpha. Proc Natl Acad Sci US A. 1994;91(4):1198-1205.

28. Wagstaff J, Smith D, Nelmes P, Loynds P, Crowther D. A phase I study of recombinant interferon gamma administered by sc injection three times per week in patients with solid tumours. Cancer Immunol Immunother. 1987;25(1):54-58.

29. Fischer JR, Schindel M, Stein N, et al. Selective suppression of cytokine secretion in patients with small-cell lung cancer. Ann Oncol. 1995;6(9):921-926.

30. DeSantis C, Naishadham D, Jemal A. Cancer statistics for African Americans, 2013. CA Cancer J Clin. 2013 May;63(3):151-66.

\section{Publish your work in this journal}

Drug Design, Development and Therapy is an international, peerreviewed open-access journal that spans the spectrum of drug design and development through to clinical applications. Clinical outcomes, patient safety, and programs for the development and effective, safe, and sustained use of medicines are a feature of the journal, which

\section{Dovepress}

has also been accepted for indexing on PubMed Central. The manuscript management system is completely online and includes a very quick and fair peer-review system, which is all easy to use. Visit http://www.dovepress.com/testimonials.php to read real quotes from published authors. 